\title{
STENOFI \\ RESEARCH ARTICLE \\ Morphological study of the gastrointestinal tract of Larimichthys crocea (Acanthopterygii: Perciformes)
}

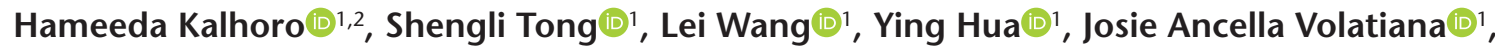 \\ Qingjun Shao (i) 1
}

\begin{abstract}
'Aquaculture Nutrition Laboratory, College of Animal Sciences, Zhejiang University. Hangzhou 310058, China. ${ }^{2}$ Department of Fresh Water Biology and Fisheries, Faculty of Natural Sciences, University of Sindh Jamshoro. Jamshoro 76080, Pakistan.

Corresponding author: Qingjun Shao (qjshao@zju.edu.cn)
\end{abstract}

http://zoobank.org/E6F123A8-B168-4AB7-A45F-F0FD375051A1

\begin{abstract}
The present study aimed to investigate the macroscopic and histological structure of the gastrointestinal tract (GIT) of Larimichthys crocea (Richardson, 1846). It consists of esophagus, stomach regions, pyloric caeca, intestinal regions, and rectum. Sixteen tubular light yellowish pyloric caeca of similar sizes were observed in all individuals. The digestive wall consists of mucosa, submucosa, muscularis, and adventitia. No major differences appeared in the structure of the tunica, epithelial cell types, connective tissues and musculature glands of L. crocea GIT. The mucosal epithelia in the oesophagus has longitudinal branched folds with frontward and hindmost zones. The gastric tunica mucosa has a characteristic folded structure and can be divided into three regions. The intestinal tunica mucosa is characterized by villi structures and numerous mucus-secreting cells. Mucus-secreting goblet cells were strongly positive to $\mathrm{AB}$ at $\mathrm{pH} 2.5$ in the oesophagus (excluding gastro-oesophageal junction) and intestine mucosal regions, which indicates an abundance of carboxylate mucins. The surface epithelia of the gastric mucosa is PAS-positive and AB-negative. SEM examination revealed that cells in the epithelium of the esophagus have an unbroken apical layer and goblet cells. The intestinal coefficient (IC) of L. crocea was $0.80 \pm 0.21$, consistent with a carnivorous or omnivorous habit. Our study adds the knowledge of the digestive system of $L$. crocea and might be useful in the management of $L$. crocea stocks.
\end{abstract}

KEY WORDS. Anatomy, epithelial mucins, gastrointestinal tract, intestinal coefficient, large yellow croaker.

\section{INTRODUCTION}

Morphological studies help in understanding the relationship between physiological and biochemical functions and molecular mechanisms. The gastrointestinal tract (GIT) of fish has shown a remarkable diversity of morphological and functional traits, particularly in connection with unusual nutritional behaviors, body shape and sex (Díaz et al. 2008b, Kapoor et al. 1975). There have been many contributions on the morphology of the GIT structure of fish, including marine, freshwater and estuarine species (Murray et al. 1994, Park and Kim 2001). Furthermore, due to various structural differences in the GIT of fish, nutritional studies have been the focus of most research in the field. For instance, past research has tried to correlate morpho functional characters of the GIT of fish with their nutritional habits and behaviors, the results of which are important to commercial fish management.
The large yellow croaker, Larimichthys crocea (Richardson, 1846), known as drums or croakers in reference to the repetitive drumming echoes they make, belong to Sciaenidae (Ramcharitar et al. 2006). This important carnivorous marine fish species is cultivated in many Asian countries, particularly China (Feng and Cao 1979). The ontogenetic development of the digestive tract of $L$. crocea was briefly described by Mai et al. (2005). Young fish start out with a simple, indistinguishable GIT that changes during development according to the environmental conditions and prey availability (Govoni et al. 1986). Functional differences in the GIT of fish are reflected in their capacity to digest, absorb and assimilate chemical compounds and are also associated with the developmental situation (Dabrowski 1984). In aquaculture, studying the anatomical and histological characteristics of the GIT of fish may help to understand the development of pathological conditions, to devise nutritional formulations and promote the management of $L$. crocea stocks 
in aquaculture. The primary goal of the present study was to describe the macroscopic and histological organization of the GIT of L. crocea.

\section{MATERIAL AND METHODS}

Twelve mature $L$. crocea were obtained from the Marine Fisheries Research Institute of Zhejiang Province, Zhoushan, China. After being anesthetized with tricaine methanesulfonate, MS 222; Sigma Chemical Co. solution by using a dosage of 100 $\mathrm{mg} \mathrm{L}^{-1}$, the fish were euthanized via a longitudinal incision through their ventral side. The length of the intestine was measured to the nearest millimeter, using a tape measure and the intestinal coefficient (IC) was calculated using the equation IC $=$ IL/SL (Angelescu and Gneri 1949). The segmental tissue fragments were removed after dissection and immediately processed for histological, histochemical and scanning electron microscopic studies.

Sliced tissue fragments from the separated GIT were fixed in 10\% formalin (for 24 hours). After fixation, tissues were repeatedly washed in $70 \%$ ethanol and dehydrated via ethanol series. Then tissues were cleared in xylene and embedded using paraffin wax at $56-58{ }^{\circ} \mathrm{C}$. Sections were sliced at $5 \mu \mathrm{m}$ using a 820 HistoStat Reichert Rotatory Microtome (Reichert Technologies, NY, USA). After routine histological procedure, dewaxed sections were stained with haematoxylin - eosin (HE) solutions. Stained slides were examined and photographed under Olympus B202 microscope (Olympus Optical, Ltd, Tokyo, Japan).

The fragments were preserved and processed similarly to the procedure described above. Five to seven $\mu \mathrm{m}$ sections were prepared and stained in Periodic acid-Schiff (PAS), Alcian blue $(\mathrm{AB} \mathrm{pH} 2.5)$ and $\mathrm{PAS}+\mathrm{AB} \mathrm{pH} 2.5$ to identify the neutral and acidic mucins respectively.

The sample processing method for scanning electron microscopy is described elsewhere in detail (Kalhoro et al. 2017). In brief, tissues were fixed in 4\% paraformaldehyde and $2.5 \%$ glutaraldehyde in phosphate buffer ( $\mathrm{pH} 7.0$ ) (for 24 hour at 4 ${ }^{\circ} \mathrm{C}$ ). After fixation, tissues were post-fixed for $1-2$ hours in $1 \%$ osmium tetroxide ( $\mathrm{pH}$ 7.0) and desiccated in a graded ethanol sequence placed in a mixture of alcohol and isoamyl acetate (v: $\mathrm{v}=1: 1$ ) about 30 minutes, then shifted to pure isoamyl acetate for overnight. Finally, tissues were washed and desiccated in Hitachi Model HCP - C critical-point dryer through liquid $\mathrm{CO}_{2}$. Desiccated samples were coated with gold-palladium in Hitachi Model E-1010 ion sputter for 4-5 minutes and observed in SEM (TM-1000, Hitachi, Japan).

\section{RESULTS}

Gross anatomy

The body measurements obtained to $L$. crocea $(n=12)$ were: body weight $(198.79 \pm 20.36 \mathrm{~g})$, total body length $(25.83$ $\pm 1.01 \mathrm{~cm})$, mean standard length $(22.78 \pm 1.00 \mathrm{~cm})$, intestinal length $(18.29 \pm 4.76 \mathrm{~cm})$ and intestinal coefficient $(0.80 \pm 0.21$ IC). The GIT of $L$. crocea consists of the esophagus, stomach regions, pyloric caeca, intestinal regions, and rectum. The short esophagus connects the pharyngeal cavity with the stomach. The $\mathrm{u}$-shaped stomach is a muscular sack between the esophagus and the anterior intestine and sits behind the liver. Sixteen tubular light yellowish pyloric caeca of similar sizes were observed in all individuals. The short intestine extends from the pyloric region of the stomach to the rectum and can be divided into anterior, middle and posterior regions (Fig. 1).

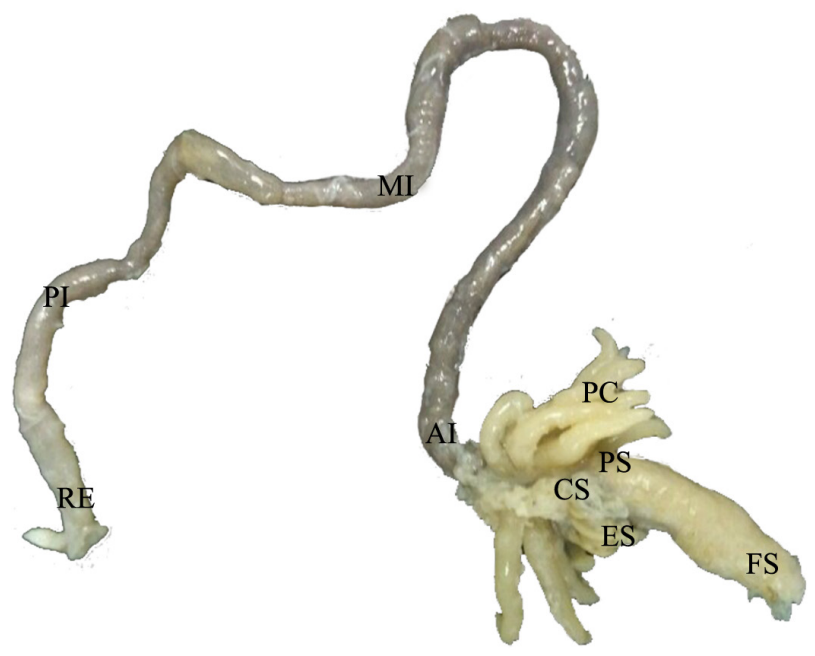

Figure 1. Photograph of the L. crocea gut illustrating: (ES) esophagus, (CS) cardiac stomach, (FS) fundic stomach, (PS) pyloric stomach, (PC) pyloric caeca, (Al) anterior intestine, (MI) mid intestine, (PI) posterior intestine, and (RE) rectum. Scale bar $=7 \mathrm{~cm}$.

Histology and scanning electron microscopy (SEM)

The digestive wall consists of mucosa, submucosa, muscularis, and adventitia. No major differences were observed at the structure of the tunic structure, epithelial cell types, connective tissues and musculature glands in the GIT of L. crocea with respect to other observed individuals. The tunica muscularis of the esophagus appears rigid, forming two muscular layers, inner longitudinal layer, and outer circular layer. The tunica muscularis in the stomach is also rigid and forms two smooth muscular layers, inner circular layer, and outer longitudinal layer. The mucosal surface in the proximal intestine has numerous elongated and deep folds lined by simple columnar goblet cells. In the distal intestine, the folds are fewer and shorter, containing large numbers of goblet cells, and no glands in the mucosa and submucosa. The absence of muscularis mucosa prevented a distinct separation between the lamina propria and the submucosa. The tunica muscularis in the intestine is organized in 


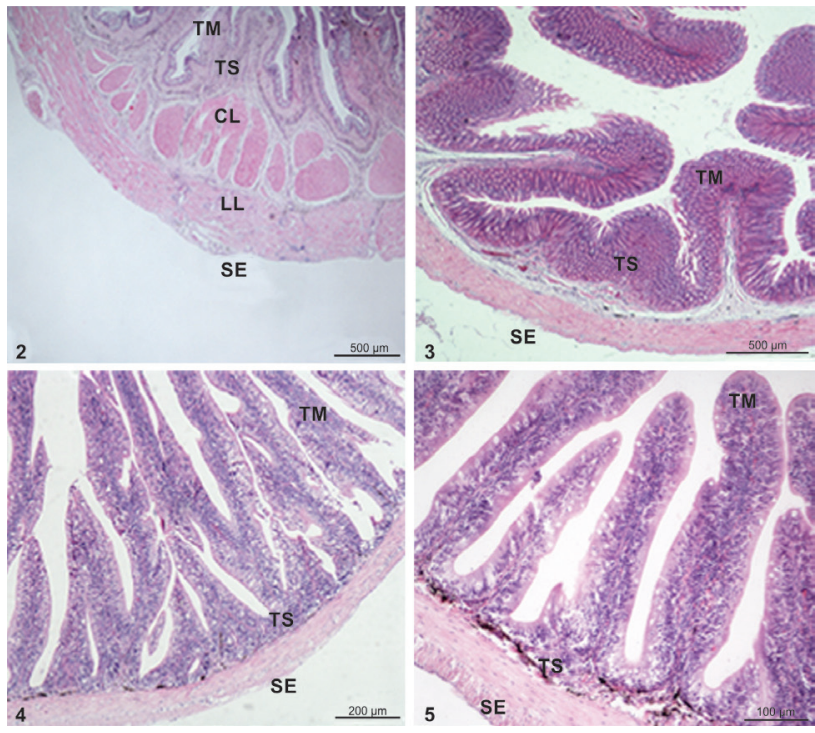

Figures 2-5. Photograph of $L$. crocea GIT illustrating the general organization: (2) transversal section of the oesophagus, note the muscular possessing an inner longitudinal layer and an outer circular layer; (3) transversal section of stomach showing the muscularis mucosa; (4) anterior intestine possessing longitudinal villi and thin muscular layer; (5) posterior intestine possessing short villi and thick muscular layer. Hematoxylin and eosin stain. (TM) Tunica mucosa, (TS) tunica submucosa, (CL) circular layer, (LL) longitudinal layer, (SE) serosa.

two smooth muscle layers; inner circular and outer longitudinal layers (Figs 2-5).

The esophageal tunica mucosa has deeper longitudinal branched folds. Frontward or anterior and hindmost or posterior regions in the epithelium are present. Stratified squamous cells are present in the frontward zone, with an increased concentration of slightly undifferentiated multilateral mucous secreting cells surmounting a deep basal cell layer that opens towards the esophageal lumen (Figs 6, 7). Squamous stratified epithelia are eventually replaced, in the hindmost zone, by simple columnar epithelia, performing secretive functions. The stratum compactum is surrounded by densely packed connective tissue fibers and detaches the tunica mucosa from the tunica submucosa. The tunica submucosa is made of loose connective tissue. Stratification of the outermost covering tunica adventitia irregular, as in other isolated parts of the mesothelium with slight underlying loose connective tissue. In other places, the tunica adventitia underlines with a thick connective tissue layer where blood vessels fold, extending from the esophageal wall, and containing large blood vessels.

Under the SEM, cells in the epithelium of the esophagus are visible on an unbroken apical layer along with goblet cells (Fig. 25). Aperture of Goblet cells revealing expelled mucus (Fig.

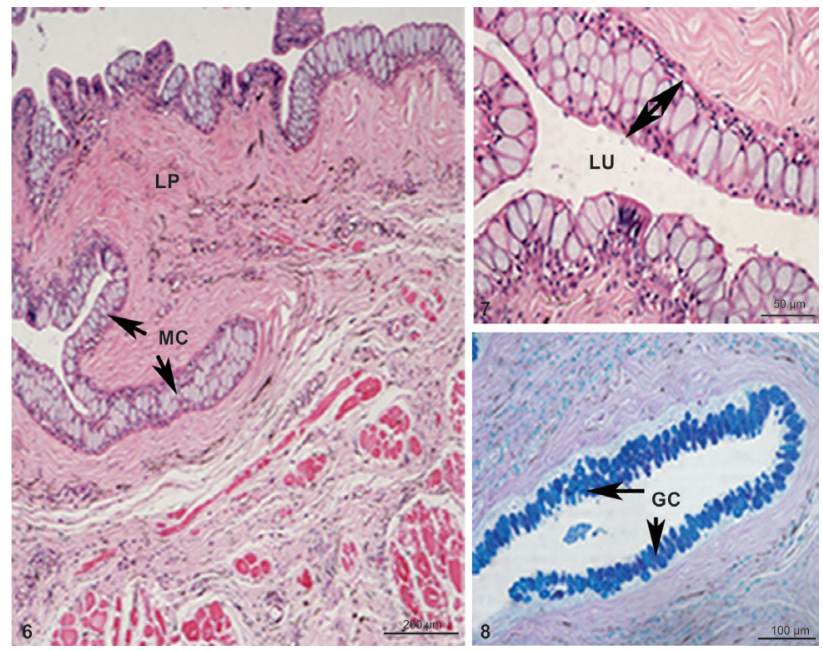

Figures 6-8. Photograph illustrating the transverse section of oesophagus containing mucus cells (arrow), lamina propria and lumen (6-7 stained with Hematoxylin and eosin stain). (8) Mucus-secreting cells in the anterior part of the oesophagus (arrows) possessing neutral and acidic carboxylated and sulphoglycoprotein. Combined stain of Periodic acid-Schiff + Alcian blue pH 2.5. (MC) Mucus cells, (LP) lamina propria, (LU) lumen, (GC) goblet cells.

26). Apical epithelia lined with a monolayer of goblet cells in increased concentrations, goblet cells filled with secretory granules and occupying most of the cytoplasm.

There is a definite change in the epithelium of the mucosa at the gastro-esophageal junction. The boundary between these two areas is conspicuous, with short non-glandular mucosal area at esophageal-gastric connection and a transition from squamous epithelium with goblet cells in the esophagus to a simpler columnar epithelium lacking goblet cells in the gastric region (Figs 9, 10). The striated muscle fibers of the esophagus are progressively replaced with smooth muscle in the cardiac stomach, and the circular muscle layer is internal to the new longitudinal muscle layer (Fig. 11).

Similar to the esophagus, the gastric mucosa has distinctive folds. The mucosa is lined with columnar epithelia and can be divided into three regions: cardiac, fundic and pyloric (Figs 13-15). The lamina propria and stratum compactum are observable. Gastric pits have a gland opening from the basal part that appear entirely distinct in the pyloric region. Glands and mucus-secreting cells predominate within the cardiac and fundic parts (Fig. 16). SEM confirmed the tall mucosal folds of the stomach within the distal part and the presence of cardiac as well as fundic glands (Figs 27, 28).

The mucosal structure of the pyloric caeca is formed by lengthy thin bends, lined with simple columnar epithelia, rare mucus-secreting goblet cells and loose connective tissue within lamina propria and small blood vessels (Fig. 17). Epithelia with 


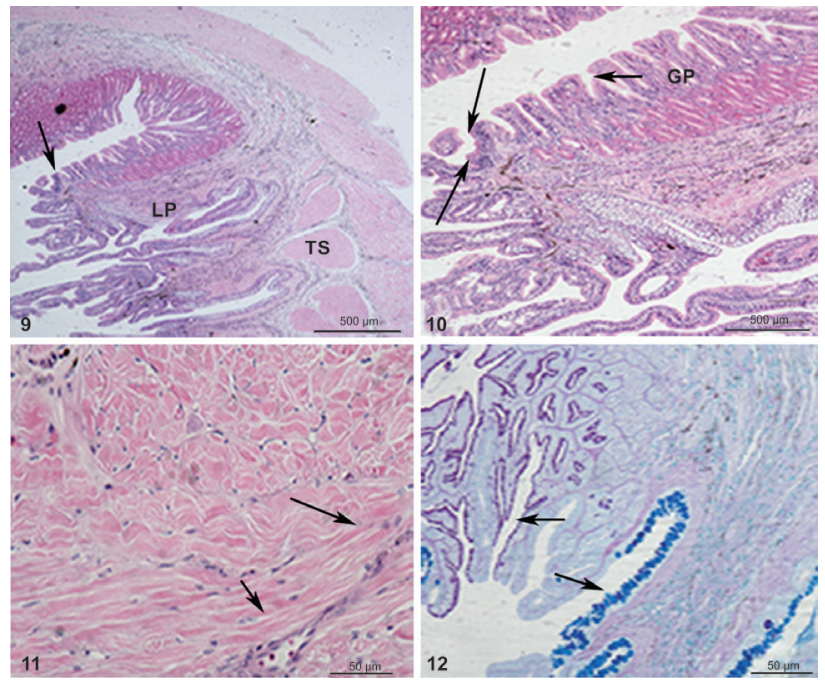

Figures 9-12. Photograph illustrating the changing of oesophageal epithelium to the gastric epithelium (arrow) in (9) and (10). Note the short non-glandular mucosal region of the gastric epithelium, (11) replacement of striated muscle by smooth muscle and (12) rapid transform of oesophageal epithelia with goblet cells (arrow) to gastric epithelia with epithelial cells containing apical mucosubstances. (9-11) stained with Hematoxylin and eosin stain and (12) stained with the combined stain of Periodic acid-Schiff + Alcian blue pH 2.5. (LP) Lamina propria, (TS) tunica submucosa, (GP) gastric pits.
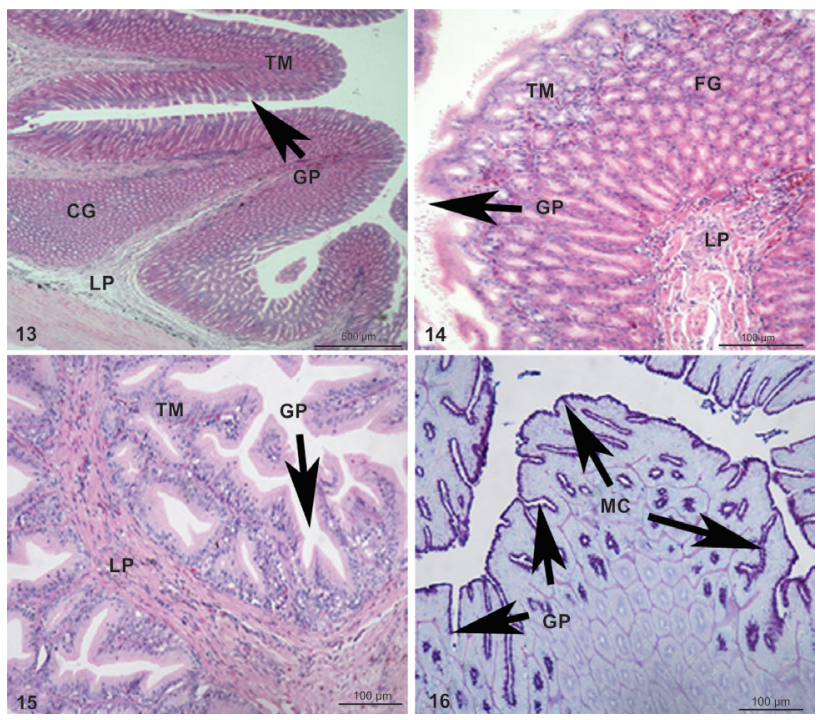

Figures 13-16. Photograph illustrating the cardiac, fundic and pyloric regions in (13), (14), and (15) respectively stained with Hematoxylin and eosin stain and (16) stained with the combined stain of Periodic acid-Schiff + Alcian blue pH 2.5. (TM) Tunica mucosa, (GP) gastric pits, (CG) cardiac gland, (FG) fundic gland, (LP) lamina propria, (MC) mucus-secreting cells.

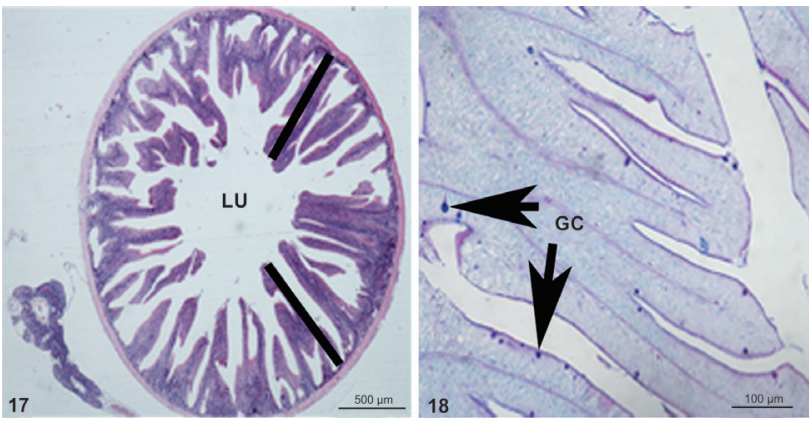

Figures 17-18. Photograph illustrating the transverse section of pyloric caeca that histologically resembles with intestine, but with exception of the higher quantity of goblet cells (arrows), (17) stained with Hematoxylin and eosin stain and (18) stained with the combined stain of Periodic acid-Schiff + Alcian blue pH 2.5. (LU) Lumen, (GC) goblet cells.

absorptive cells are responsible for nutrient absorption. No tunica submucosa is present. In its place there is a thin circular layer of smooth muscle.

Though no macroscopic differences can be observed in the intestine, in histological terms it is divided into anterior, middle and posterior intestines (Figs 19-21). The tunica mucosa is characterized by the presence of single-layered epithelia, mostly consisting of enterocytes, mucus-secreting epithelium cells and no propria glands. Intraepithelial lymphocytes (IEL) are also observed in the epithelia. The superficial epithelial layer of all regions is covered by microvilli (brush border). The underlying connective tissue is scattered, containing blood vessels and nerves. Since the mucosal muscular thin layer is absent, the muscular mucosal thin layer and tunica submucosa are inconspicuous. The SEM observation on the anterior intestine shows the organization of longitudinal mucosal folds with visible intestinal crypts (Fig. 29). Distally along the intestinal segments, the high mucosal folds appear loosely organized and have asymmetrical structure. The folds decrease in size distally along the intestinal tube. Microvilli and the goblet cells opening towards luminal surface are visible on the posterior intestine (Fig. 30).

Mucin histochemistry

Histochemical analysis of epithelial mucins in the $L$. crocea GIT revealed secretory cells and goblet cells in the esophagus and intestine, and epithelial cells in the stomach. Mucus-secreting goblet cells were strongly positive to $\mathrm{AB}$ at $\mathrm{pH}$ 2.5 in the esophagus (excluding gastro-esophageal junction) and the mucosal regions of the intestine have great amounts of carboxylated mucins. The surface epithelia of the gastric mucosa were PAS-positive and AB-negative (Fig. 16); a gel-like structure is formed by acidic mucins covering the epithelia of the esophagus (Fig. 8). The pyloric caeca are positive for PAS 


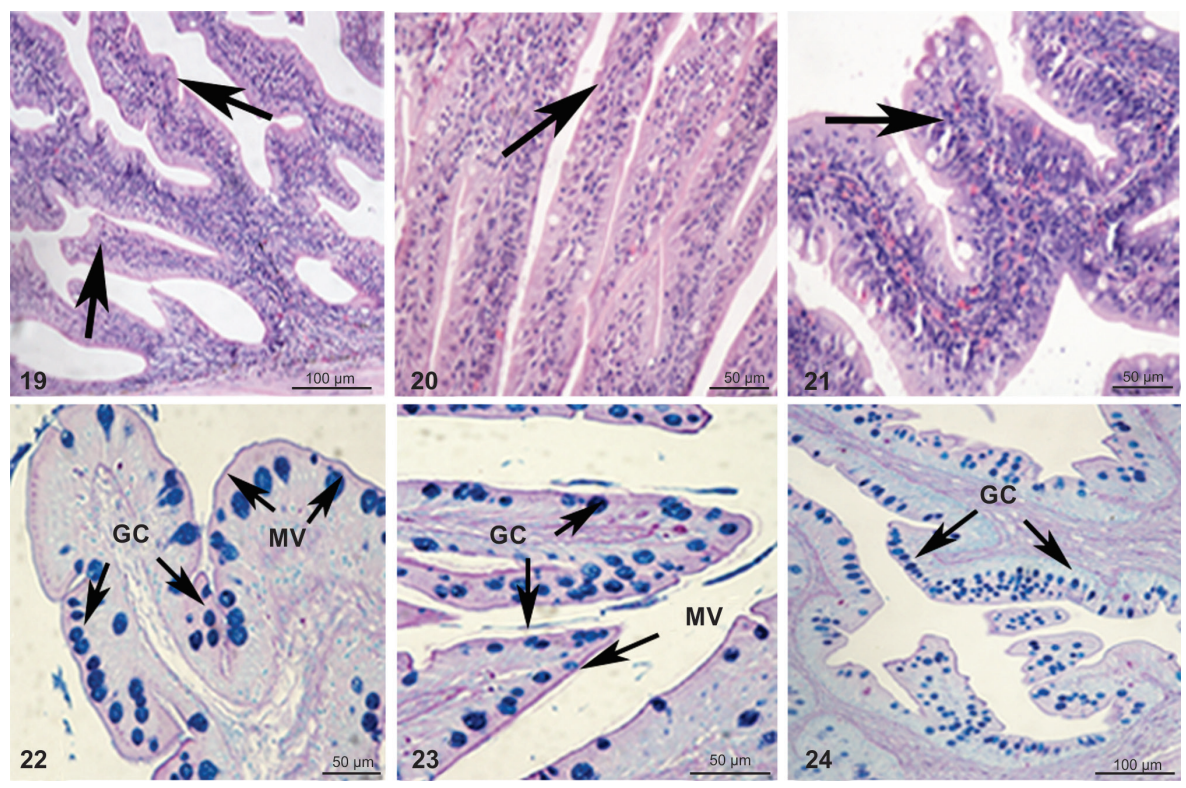

Figures 19-24. Photograph illustrating the anterior, mid and posterior regions in (19, 22), (20, 23) and (21, 24), respectively. (19-21) stained with Hematoxylin and eosin stain and (22-24) stained with the combined stain of Periodic acid-Schiff + Alcian blue pH 2.5. (GC) Goblet cells, (MV) microvilli.
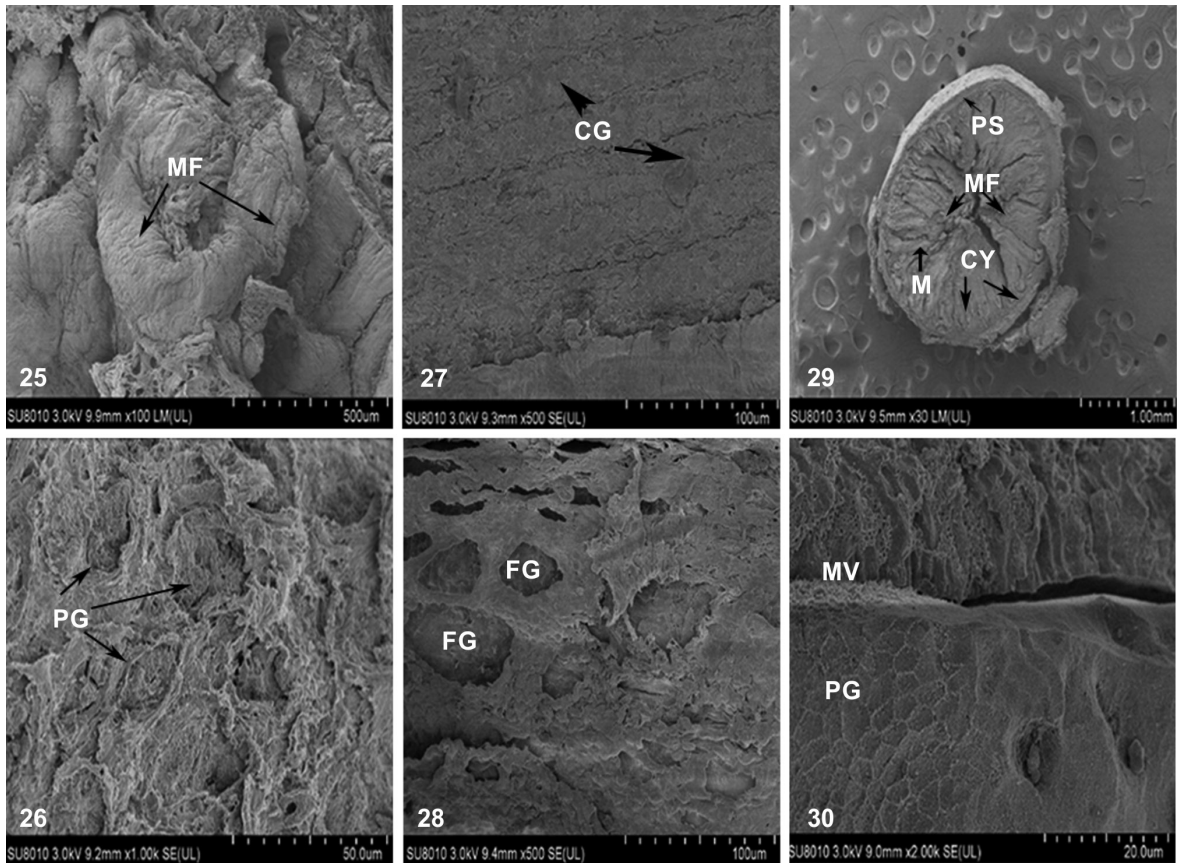

Figures 25-30. Scanning electron microscopy illustrating (25) epithelial surface of the oesophagus (26) pores of goblet cells (27) epithelial surface of the cardiac stomach showing cardiac gland (28) fundic region of the stomach showing fundic glands (29) Cross-section of the anterior intestine showing longitudinal mucosal folds, crypts, propria-submucosa and tunica muscularis (30) posterior intestine showing microvilli and pores of goblet cell. (M) Mucosa, (MF) mucosal fold, (PG) pores of goblet cells, (CG) cardiac gland, (PS) propria-submucosa, (FG) fundic gland, (CY) crypts, (MV) microvilli. 
and negative for $\mathrm{AB}$ at $\mathrm{pH} 2.5$, indicating neutral glycoproteins secretion (Fig. 18). The combined reaction of PAS $+\mathrm{AB} \mathrm{pH} 2.5$ showed a bluish staining of intestinal mucus-secreting goblet cells (Figs 22-24). The epithelium of the esophagus is unstained in the combined reaction of $\mathrm{PAS}+\mathrm{AB} \mathrm{pH} 2.5$. Moreover, the oxynticopeptic cells of gastric glands reacted positively to the PAS reaction (Fig. 12) (Table 1).

\section{DISCUSSION}

Morphological studies on the GIT of fish are useful when developing strategies for the management and conservation of fish species (Germano et al. 2014, Xiong et al. 2011). Our results revealed some peculiarities of the GIT of $L$. crocea, including the rather uniform structure of a shorter esophagus, well-developed stomach, pyloric appendages, and intestine.

In teleosts, the length of the intestine is correlated with nutritional habits (Canan et al. 2012, Machado et al. 2013). On the basis of the IC obtained (0.80), L. crocea can be categorized as omnivorous or carnivorous (0.2-2.5) (Bertin 1958), whereas the intestinal coefficient assortment for omnivorous (0.6-8.0) and herbivorous (0.8-15.0) teleosts is far greater (Al-Hussaini 1949, Bertin 1958, Xiong et al. 2011). However, some herbivorous teleosts have short intestines with less intestinal coefficients (Takesue 1954).Thus the intestinal coefficient might only be a criterion-referenced factor for classification of fish feeding habits.

Similar to other teleosts, the esophageal mucosa of $L$. crocea has squamous epithelium (frontward zone) and columnar epithelium (hindmost zone) (Carrassón et al. 2006, Cataldi et al. 1987). Frontward, the mucous cells of the epithelium contain sialosulphon glycoproteins. This secretion increases in the frontward zone and most likely protect the anterior region of the esophagus. The histochemical staining reacted positively, confirming the function of mucus in regulating lubrication (Oliveira Ribeiro and Fanta 2000). The lack of taste buds and lamina muscularis mucosae indicates that this organ has the function of pushing the swallowed micronutrients towards the gut (Ezeasor 1984). The submucosal part is a thick layer of connective tissue associated with a thick muscle layer, which might be compensate for the absence of a mucosal muscular layer (Albrecht et al. 2001). In fish, abundant mucous cells in the esophagus help food pass to the stomach (Cataldi et al. 1987, Grau et al. 1992); those cells are equivalent to esophageal glands found in the lamina propria or in the submucosa of higher vertebrates (Andrew and Hickman
1974). The formation of striated skeletal muscle fibers present in the esophageal wall found in $L$. crocea has also been observed in Stegastes fuscus (Cuvier, 1830), Pterodoras granulosus (Valenciennes, 1821) and Oligosarcus hepsetus (Cuvier, 1829) (Canan et al. 2012, Germano et al. 2014, Vieira-Lopes et al. 2013). It provides expeditious mobility with powerful contractions to clear the esophageal lumen (Chaves and Vazzoler 1984). As observed in our study, the presence of muscular layers in the esophagus (longitudinal inner sublayer and circular outer sub layer) and striated muscles that may possibly expand the luminal surface area of the esophagus, enable food intake and have been similarly observed in other Sciaenidae species such as Micropogonias furnieri (Desmarest, 1823) (Diaz et al. 2008a, b) and other teleosts; Hemisorubim platyrhynchos (Valenciennes, 1840) (Faccioli et al. 2014) and Odontesthes bonariensis (Valenciennes, 1835) (Diaz et al. 2006). In many teleostean families, the stomach is absent (Genten et al. 2009). However, it is developed in Sciaenidae (Andrade et al. 2017). The stomach of $L$. crocea has a U-shaped saccular structure, as reported by Pessoa et al. (2013) for Hypostomus pusarum (Starks, 1913) and by Andrade et al. (2017) in M. furnieri. A U-shaped stomach fundus characterizes a debris-eater (Moraes et al. 1997), while a Y-shaped, caecum sort of stomach is adapted to the assimilation of the entire prey (Rodrigues et al. 2008). The gastric glands are the main part of the gastric mucosa in vertebrates and teleost species (Al Abdulhadi 2005). The epithelium of L. crocea contains tubular gastric glands in cardiac and fundic regions, as reported in Sparus aurata Linnaeus, 1758, Pelteobagrus fulvidraco (Richardson, 1846), Glyptosternum maculatum (Regan, 1905) and Hemisorubim platyrhynchos (Valenciennes, 1840) (Cao and Wang 2009, Cataldi et al. 1987, Faccioli et al. 2014, Xiong et al. 2011). Our results showing an absence of gastric glands within the pyloric part of the stomach confirm the results reported by (Clarke and Witcomb 1980, Purushothaman et al. 2016). On the other hand, Arellano et al. (2001) reported that gastric glands were absent from the cardiac part of the stomach, while tubular glands within the pyloric part of the stomach were reported for a few teleosts by Al-Hussaini (1949). The gastric mucosa of $L$. crocea consists epithelial cells rich in neutral mucins similarly as reported for other teleosts (Cao and Wang 2009, Cataldi et al. 1987, Hernández García et al. 2001), formed by microvilli that may possibly serve in nutritive absorption (Grau et al. 1992, Ortiz-Delgado et al. 2003). On the other hand, this secretion from neutral mucous may protect epithelia from auto-digestion by hydrochloric acid and gastric glands secretion (Ferraris et al. 1987).

Table 1. Histochemical techniques of mucosubstances in epithelia of the Larimichthys crocea gastrointestinal tract.

\begin{tabular}{|c|c|c|c|c|c|c|c|}
\hline \multirow[t]{2}{*}{ Procedure } & \multicolumn{7}{|c|}{ Region } \\
\hline & Oesophagus & Cardiac stomach & Fundic stomach & Pyloric stomach & Pyloric caeca & Anterior intestine & Posterior intestine \\
\hline PAS & ++ & ++ & ++ & ++ & + & ++ & ++ \\
\hline $\mathrm{AB} p \mathrm{pH} 2.5$ & - & - & - & - & ++ & ++ & ++ \\
\hline $\mathrm{AB}+\mathrm{PAS}(\mathrm{pH} 2.5)$ & + & + & + & + & + & ++ & ++ \\
\hline
\end{tabular}

Staining reaction: $(-)$ negative; $(+)$ medium; $(++)$ strong. 
Pyloric caeca or tubular pouches vary in size and quantity according to the nutritional habits of teleosts (Canan et al. 2012, Purushothaman et al. 2016). Sixteen tubular pouches of almost similar sizes were observed in $L$. crocea. A different amount has been found in different teleost such as 10 in Leporinus friderici (Bloch, 1794), 4 tubular pouches in Acanthopagrus schlegelii (Bleeker, 1854) and 5 in Lates calcarifer (Bloch, 1790) respectively (Albrecht et al. 2001, Kalhoro et al. 2017, Purushothaman et al. 2016). It is predicted that the number of intestinal caeca and the length of the intestine are greater in herbivorous species, intermediate in omnivorous ones, and minimized in carnivorous fish, but is not always consistent (Alonso et al. 2015). From a histological categorization, the tunica mucosa has simple prismatic epithelia with mucus-secreting cells and longitudinal folded structure. The chief purpose of the tubular pouches is explained as "absorption" in contrast with mammals that function as fermentation. These are filled up as well as collapsed together by the anterior intestine, expanding the entire absorptive surface.

The intestinal mucosa is covered by columnar epithelia (enterocytes) and dominant mucus cell type called the goblet cell, like in other teleosts. Carrassón et al. (2006) stated that gel-forming mucin secretion produced by these goblet cells is involved in epithelial protection as well as in lubrication for nutrient pass way. The increased concentration of mucus-secreting cells appearing from the anterior to the posterior region followed by the rectum indicate that mucous production help to defend the lining of the intestine and support waste exclusion (Machado et al. 2013). The mucus-secreting goblet cells of L. crocea reacted positively to PAS (neutral mucins), specifying that these mucins might be involved in providing co-factors that are essential to nutrients enzymatic breakdown (Anderson 1986), and AB-positive reaction (acidic mucins) specified that these mucins shield the intestinal surface from glycosidase deprivation (Carrassón et al. 2006). As defined by Pelaseyed et al. (2014), mucus-secreting goblet cells are frequently dispersed among enterocytes. They have glycoproteins and are released by exocytosis of the intestinal epithelium, as observed in this study. Their abundance and secretive material are dependent on environmental factors (Rogers 1994). Various glycosaminoglycan or mucopolysaccharides eventually interact in the digestion process. In our study, the secretion of acid mucopolysaccharides suggest a secretory role of the intestinal epithelia. Moreover, these acid mucopolysaccharides are known to be sulfated peptic protease inhibitors that are useful in preventing pathogenic infections and providing protection from mechanical actions (Campbell 1999). Neutral mucopolysaccharides are associated with the function of digesting and emulsifying nutrients (Clarke and Witcomb 1980). Besides, it can be assumed that the chemical nature and the amount of mucus may influence the nature of the nutrients swallowed (Pelaseyed et al. 2014). This statement might support the increased concentration of goblet cells found from the anterior to the posterior intestinal regions in our study. Moreover, finding the intraepithelial lymphocytes (IEL) with the epithelial cells and mucus-producing cells indicate an active role in the teleost gut immune response. Particularly, they are involved in a regulatory function increasing the lymphocytic number in the intestinal mucosa, indicating the presence of a mucosal immune system (Miura et al. 2012).

On the basis of our results, the morphology of the GIT of L. crocea is consistent with omnivorous and carnivores feeding habits. Further detailed studies should be conducted on the ultrastructure level of the gastrointestinal tract of $L$. crocea.

\section{ACKNOWLEDGEMENTS}

This study was supported by Zhejiang Provincial Bureau of Science and Technology (Project 2015C02020, 2015C03010) and Zhejiang Aquaculture Nutrition \& Feed Technology Service Team (ZJANFTST2017-1). We would like to thank the China-Norwegian Joint Laboratory of Nutrition and Feed for Marine Fish (Xixi Island, Zhoushan, Zhejiang Province) for their technical assistance.

\section{LITERATURE CITED}

Al-Hussaini AH (1949) On the functional morphology of the alimentary tract of some fish in relation to differences in their feeding habits; anatomy and histology. The Quarterly journal of microscopical science 90: 109-139

Al Abdulhadi HA (2005) Some comparative histological studies on alimentary tract of tilapia fish (Tilapia spilurus) and sea bream (Mylio cuvieri). Egyptian Journal of Aquatic Research 31: 387397.

Albrecht MP, Ferreira MFN, Caramaschi EP (2001) Anatomical features and histology of the digestive tract of two related neotropical omnivorous fishes (Characiformes; Anostomidae). Journal of Fish Biology 58: 419-430. https://doi.org/10.1006/ jfbi.2000.1462

Alonso F, Mirande JM, Pandolfi M (2015) Gross anatomy and histology of the alimentary system of characidae (Teleostei: Ostariophysi: Characiformes) and potential phylogenetic information. Neotropical Ichthyology 13: 273-286. https://doi. org/10.1590/1982-0224-20140137

Anderson TA (1986) Histological and cytological structure of the gastrointestinal tract of the luderick, Girella tricuspidata (pisces, kyphosidae), in relation to diet. Journal of Morphology 190: 109-119. https://doi.org/10.1002/jmor.1051900110

Andrade IM, Guimarães JP, Rotundo MM, Mari RB (2017) Morphology of the digestive tract of the Whitemouth croaker Micropogonias furnieri (Desmarest, 1823) (Perciformes: Sciaenidae). Acta Zoologica 98: 136-143. https://doi.org/10.1111/ azo.12156

Andrew W, Hickman CP (1974) Histology of the vertebrates: a comparative text. Mosby, St Louis, 243-296 pp.

Angelescu V, Gneri FS (1949) Adaptaciones del aparato digestivo al régimen alimentício em algunos peces Del rio Uruguay y Del rio de la Plata. I. Tipo omnivoro e iliofago em representantes 
de las familias Loricariidae y Anostomidae. Revista del Museo Argentino de Ciencias Naturales "Bernardino Rivadavia" 1(6): 161-272.

Arellano JM, Storch V, Sarasquete C (2001) Histological and histochemical observations in the stomach of the Senegal sole, Solea senegalensis. Histology and Histopathology 16: 511-521. Bertin L (1958) Appareil digestif. Traité de Zoologie 13: 1249-1301. Campbell BJ (1999) Biochemical and functional aspects of mucus and mucin-type glycoproteins. In: Mathiowitz E, Chickring DE III, Lehr C-M (Eds) Bioadhesive drug delivery systems. Marcel Dekker Inc, New York, 85-130. https://doi.org/10.1201/ b14099-6

Canan B, Nascimento WSD, Silva NBD, Chellappa S (2012) Morphohistology of the digestive tract of the damsel fish Stegastes fuscus (Osteichthyes: Pomacentridae). The Scientific World Journal 2012: 787316. https://doi.org/10.1100/2012/787316

Cao XJ, Wang WM (2009) Histology and mucin histochemistry of the digestive tract of yellow catfish, Pelteobagrus fulvidraco. Anatomia Histologia Embryologia 38: 254-261. https://doi. org/10.1111/j.1439-0264.2009.00932.x

Carrassón M, Grau A, Dopazo LR, Crespo S (2006) A histological, histochemical and ultrastructural study of the digestive tract of Dentex dentex (Pisces, Sparidae). Histology and Histopathology 21: 579-593.

Cataldi E, Cataudella S, Monaco G, Rossi A, Tancioni L (1987) A study of the histology and morphology of the digestive tract of the sea-bream, Sparus aurata. Journal of Fish Biology 30: 135-145. https://doi.org/10.1111/j.1095-8649.1987. tb05740.x

Chaves PDTDC, Vazzoler C (1984) Aspectos biológicos de peixes amazônicos. III. Anatomia microscópica do esôfago, estômago e cecos pilóricos de Semaprochilodus insignis (characiformes: Prochilodontidae). Acta Amazonica 14: 343-354. https://doi. org/10.1590/1809-43921984143353

Clarke AJ, Witcomb DM (1980) A study of the histology and morphology of the digestive tract of the common eel (Anguilla anguilla). Journal of Fish Biology 16: 159-170. https://doi. org/10.1111/j.1095-8649.1980.tb03695.x

Dabrowski K (1984) The feeding of fish larvae: Present "state of the art" and perspectives. Reproduction Nutrition Development 24: 807-833. https://doi.org/10.1051/rnd:19840701

Diaz AO, Escalante AH, Garcia AM, Goldemberg AL (2006) Histology and histochemistry of the pharyngeal cavity and oesophagus of the silverside Odontesthes bonariensis (Cuvier and Valenciennes). Anatomia Histologia Embryologia 35: 42-46. doi: 10.1111/j.1439-0264.2005.00654.x

Diaz AO, Garcia AM, Figueroa DE, Goldemberg AL (2008a) The mucosa of the digestive tract in Micropogonias furnieri: a light and electron microscope approach. Journal of Veterinary Medicine Series C: Anatomia Histologia Embryologia 37: 251-256. https://doi.org/10.1111/j.1439-0264.2007.00837.x

Díaz AO, García AM, Goldemberg AL (2008b) Glycoconjugates in the mucosa of the digestive tract of Cynoscion guatucupa: A histochemical study. Acta Histochemica 110: 76-85. https:// doi.org/10.1016/j.acthis.2007.08.002

Ezeasor DN (1984) Light and electron microscopic studies on the oesophageal epithelium of the rainbow trout, Salmo gairdneri. Anatomischer Anzeiger 155: 71-83.

Faccioli CK, Chedid RA, Amaral ACD, Franceschini Vicentini IB, Vicentini CA (2014) Morphology and histochemistry of the digestive tract in carnivorous freshwater Hemisorubim platyrhynchos (Siluriformes: Pimelodidae). Micron 64: 10-19. https:// doi.org/10.1016/j.micron.2014.03.011

Feng Z, Cao Q (1979) Ichthyology. Beijing, Agricultural Press House, 154-155.

Ferraris RP, Tan JD, De La Cruz MC (1987) Development of the digestive tract of milkfish, Chanos chanos (Forsskal): histology and histochemistry. Aquaculture 61: 241-257. https://doi. org/10.1016/0044-8486(87)90153-0

Genten F, Terwinghe E, Danguy A (2009) Atlas of fish histology. Science Publishers Enfield,New Hampshire, 219 pp. https:// doi.org/10.1201/b10183

Germano RDM, Stabille SR, Mari RDB, Pereira JNB, Faglioni JRS, Neto MHDM (2014) Morphological characteristics of the Pterodoras granulosus digestive tube (Valenciennes, 1821) (Osteichthyes, Doradidae). Acta Zoologica 95: 166-175. https://doi. org/10.1111/azo.12016

Govoni JJ, Boehlert GW, Watanabe Y (1986) The physiology of digestion in fish larvae. Environmental Biology of Fishes 16: 59-77. https://doi.org/10.1007/BF00005160

Grau A, Crespo S, Sarasquete MC, de Canales MLG (1992) The digestive tract of the amberjack Seriola dumerili, Risso: a light and scanning electron microscope study. Journal of Fish Biology 41: 287-303. https://doi.org/10.1111/j.1095-8649.1992.tb02658.x

Hernández García MP, Lozano MT, Elbal MT, Agulleiro B (2001) Development of the digestive tract of sea bass (Dicentrarchus labrax L.). Light and electron microscopic studies. Anatomy and embryology 204: 39-57. https://doi.org/10.1007/ s004290100173

Kalhoro H, Tong S, Wang L, Hua Y, Volatiana JA, Shao QJ (2017) Gross anatomical and histomorphological features of the Acanthopagrus schlegelii (Bleeker, 1854) digestive tract Perciformes, Sparidae. Acta Zoologica. https://doi.org/10.1111/azo.12225

Kapoor BG, Smit H, Verighina IA (1975) The Alimentary Canal and Digestion in Teleosts. Advances in Marine Biology 13: 109-239. https://doi.org/10.1016/S0065-2881(08)60281-3

Machado MRF, Souza HO, de Souza VL, de Azevedo A, Goitein R, Nobre AD (2013) Morphological and anatomical characterization of the digestive tract of Centropomus parallelus and C. undecimalis. Acta Scientiarum, Biological Sciences 35: 467-474. https://doi.org/10.4025/actascibiolsci.v35i4.14352

Mai K, Yu H, Ma H, Duan Q, Gisbert E, Infante JLZ, Cahu CL (2005) A histological study on the development of the digestive system of Pseudosciaena crocea larvae and juveniles. Journal of Fish Biology 67: 1094-1106. https://doi.org/10.1111/j.00221112.2005.00812.x 
Miura S, Hokari R, Tsuzuki Y (2012) Mucosal Immunity in Gut and Lymphoid Cell Trafficking. Annals of Vascular Diseases 5: 275281. https://doi.org/10.3400/avd.ra.12.00059

Moraes MD, Barbola IF, Guedes É (1997) Alimentação e relações morfológicas com o aparelho digestivo do "curimbatá", Prochilodus Ilneatus (Valenciennes). Revista Brasileira de Zoologia 14: 169-180. https://doi.org/10.1590/S010181751997000100015

Murray HM, Wright GM, Goff GP (1994) A study of the posterior esophagus in the winter flounder, Pleuronectes americanus, and the yellowtail flounder, Pleuronectes ferruginea: A morphological evidence of pregastric digestion? Canadian Journal of Zoology 72: 1191-1198. https://doi.org/10.1139/z94-160

Oliveira Ribeiro CA, Fanta E (2000) Microscopic morphology and histochemistry of the digestive system of a tropical freshwater fish Trichomycterus brasiliensis (Lütken)(Siluroidei, Trichomycteridae). Revista Brasileira de Zoologia 17: 953-971. https://doi. org/10.1590/S0101-81752000000400007

Ortiz-Delgado JB, Darias MJ, Cañavate JP, Yúfera M, Sarasquete $C$ (2003) Organogenesis of the digestive tract in the white seabream, Diplodus sargus. Histological and histochemical approaches. Histology and Histopathology 18: 1141-1154.

Park JY, Kim IS (2001) Histology and mucin histochemistry of the gastrointestinal tract of the mud loach, in relation to respiration. Journal of Fish Biology 58: 861-872. https://doi. org/10.1111/j.1095-8649.2001.tb00536.x

Pelaseyed T, Bergström JH, Gustafsson JK, Ermund A, Birchenough $\mathrm{GMH}$, Schütte A, Post S, Svensson F, Rodríguez-Piñeiro AM, Nyström EEL (2014) The mucus and mucins of the goblet cells and enterocytes provide the first defense line of the gastrointestinal tract and interact with the immune system. Immunological Reviews 260: 8-20. https://doi.org/10.1111/imr.12182

Pessoa EKR, da Silva NB, Chellappa NT, de Souza AA, Chellappa S (2013) Morfologia comparativa do trato digestório dos peixes Hoplias malabaricus e Hypostomus pusarum do açude Marechal Dutra, Rio Grande do Norte, Brasil. Biota Amazônia 3: 48-57. https://doi.org/10.18561/2179-5746/biotaamazonia. v3n1p48-57

Purushothaman K, Syed Musthaq SK, Lunny DP, Vij S, Orban L (2016) Morpho-histological characterisation of the alimentary canal of an important food fish, Asian seabass (Lates calcarifer). Peer] 4: e2377. https://doi.org/10.7717/peerj.2377

Ramcharitar J, Gannon DP, Popper AN (2006) Bioacoustics of fishes of the family Sciaenidae (croakers and drums). Transactions of the American Fisheries Society 135: 1409-1431. https://doi. org/10.1577/T05-207.1

Rodrigues SS, Navarro RD, Menin E (2008) Anatomia do tubo digestório de Leporinus macrocephalus Garavello \& Britski, 1988 (Characiformes, Anostomidae) em relação ao seu habita alimentar. Bioscience Journal 24: 86-95.

Rogers DF (1994) Airway goblet cells: responsive and adaptable front-line defenders. European Respiratory Journal 7: 16901706. https://doi.org/10.1183/09031936.94.07091678

Takesue K (1954) Studies on the change of the digestive enzyme systems with growth of the fish, Plecoglossus altivelis Temmninck \& Schlegel. Shimonoseki Coll Fish 3: 289-294.

Vieira-Lopes DA, Pinheiro NL, Sales A, Ventura A, Araújo FG, Gomes ID, Nascimento AA (2013) Immunohistochemical study of the digestive tract of Oligosarcus hepsetus. World Journal of Gastroenterology 19: 1919-1929. https://doi.org/10.3748/ wjg.v19.i12.1919

Xiong D, Zhang L, Yu H, Xie C, Kong Y, Zeng Y (2011) A study of morphology and histology of the alimentary tract of Glyptosternum maculatum (Sisoridae, Siluriformes). Acta Zoologica 92: 161-169.

Submitted: March 21, 2018

Accepted: June 14, 2018

Available online: November 1, 2018

Editorial responsibility: Carolina Arruda Freire

Author Contributions: $\mathrm{KH}$ and SQ designed the research; $\mathrm{KH}, \mathrm{TS}$, WL, HY, VJA conducted the research; $\mathrm{KH}$ analyzed the data and wrote the paper. SQ revised the manuscript. All authors approved the final version of the manuscript.

Competing Interests: The authors have declared that no competing interests exist.

(C) 2018 Sociedade Brasileira de Zoologia. Published by Pensoft Publishers at https://zoologia.pensoft.net 